African J. Biol. Sci., 15 (1): 33-42 (2019)

ISSN 1687-4870

www.aasd.byethost13.com

e- ISSN 2314-5501 (online)

e.mail: aasdjournal@yahoo.com

\title{
Gene expression of heat shock protein (hsp90) in Plodia interpunctella and Ephestia kuehniella (Lepidoptera: Pyralidae) larvae parasitized by Bracon hebetor wasp (Hymenoptera: Braconidae)
}

\author{
Aida Said Kamel, Rawhia H. Ramadan, Faten F.Abul-Dahab, \\ Mona F. Abdel-Aziz and Heba F. Abdel-khalek \\ Entomology Department, Faculty of Science, Banha University
}

\begin{abstract}
Venoms of parasitoid wasps injected into the host may play vital roles in successful parasitism. It could manipulate the host physiology and suppress its immune response. Heat shock proteins (hsps) could be induced by a variety of physiological stresses and might play roles in modulating the host-parasitoid relationship. Quantitative real-time transcription PCR was used to determine the changes of heat shock protein90 gene in Polidia interpunctella and Ephestia kuehniella larvae post parasitization by Bracon hebtor wasp. The results indicated that hsp90 gene expression level showed different behavior in both hosts, at all-time intervals post parasitism. Expression of the gene in P. interpunctella larvae was significantly down regulated at $12 \mathrm{~h}$. A high significant down regulated was observed at 24 and $72 \mathrm{~h}$ after parasitization. Meanwhile, a high significant up-regulation was recorded after $48 \mathrm{~h}$ compared with control. On the other hand, the levels of hsp90 in E. kuehniella were high significantly down regulated in all treated larvae compared with control. We can conclude that the suppression hsp90 gene could be a component of parasitized hosts' manipulation strategy that regulate the host physiology and suppress the immune response. Hsp90 might play an important role in host paralysis and inhibit its development.
\end{abstract}

Key words: Hsp90, Polidia interpunctella, Ephestia kuehniella, Bracon hebtor,venom, wasp,parasitism.

\section{INTRODUCTION}

Heat shock proteins (hsps) are ubiquitous molecular chaperones found in all eukaryotic cells.Chaperones (stress proteins) are essential proteins to help the formation and maintenance of the proper conformation of other proteins and to promote cell survival after a large variety of environmental stresses. Therefore, normal chaperone function is a key factor for endogenous stress (Soti et al., 2005) and it has an important role in protein folding, unfolding, aggregation, degradation adaptation of several tissues.In addition, hsp often employ protective functions in response to a number of stressful environmental conditions including abiotic stresses such as heat shock, ultraviolet radiation, chemical pesticides, as well as biotic stresses such as viruses, bacteria, fungi and parasitoid insects (Zhao and Jones, 2012). Hsps are organized into several families based on their molecular mass $(\mathrm{kDa})$. They are highly conserved families that protect the cell protein against stress (Nguyen et al., 2009). They play an important function in correctly folding newly synthesized proteins, stabilizing and refolding denatured proteins after stress, preventing misfolding and aggregation of unfolded or partially folded proteins, and assisting in protein transport across the endoplasmic reticulum and organelle membranes (Young et al., 2001).

Hsp90 members have key roles in the maturation of signal transduction proteins, like hormone receptors, various kinases and nitric oxide syntheses (Wegele et al., 2004). Hsp90s are usually represented with four major types, two cytosolic forms, (alpha and -beta forms), 


\section{Aida Said Kamel et al.}

endoplasmic reticulum and mitochondrial homologues( Felts et al., 2000). The "hsp90 client proteins" are directly associated with hsp90 and they include a wide variety of signal-transducing molecules that regulate cell growth and differentiation, protein kinases and transcription factors are more essential(Krishna and Gloor, 2001).

The Indian meal moth, Polidia interpunctella(Hübner) and the Mediterranean flour moth Ephestia kuehniella (Zeller) (Lepidoptera: Pyralidae) were insect pests of storedproducts and processed food commodities throughout the world. These pests induce considerable losses to cereal, legumes grains and other high value crops such as cocoa beans and dried fruits (Mohandass $e t$ al., 2007). Parasitoids play an important role in integrated pest management programs due to their capability to keep pest populations under economic thresholds (Belda and Riudavets, 2013). In addition, Habrobracon hebetorwasp is a gregarious ectoparasitoid of Pyralid moth larvae. Its Female parasitises the larvae of several species of stored-product moths, including Indian meal moth $P$. interpunctella(Hübner), Mediterranean flour moth E. kuehniella, warehouse moth Ephestia elutella(Hübner), and the tropical warehouse moth Cadra cautellaWalker( Schölle,2010).

The ability of a parasitoid to grow within the host is influenced directly by its ability to overcome the host immune system with different strategies. Hymenopteran parasitoids have developed host-specific strategies to overthrow the host immune system, such as the use of venom, endosymbiont virus, or mimicking the host tissue (Caron et al., 2008). Bracon hebetor Say (Hymenoptera: Braconidae) is ectoparasitoid that is an important active parasitoid against several stored product moths like the Mediterranean flour moth E. kuehniella, warehouse moth Ephestia clutella, Indian meal moth $P$. interpunctella and rice moth
Corcyra cephalonica (Darwish et al., 2003; Maafi and Chi, 2006; Chen et al., 2011). It parasitizes the last instar larvae and host-larvae become paralyzed by venom a few minutes after intoxication (Sláma and Lukáš, 2011).

Several studies have demonstrated that hsps are involved in host-parasitoid interactions and immune response by the host. For example, the expression analysis of hsp20, hsp75 and hsp90 from Pieris rapae responsiveness to parasitization by the endoparasitic wasp Pteromalus puparum indicated that these three genes were influenced (Zhu et al., 2013). With respect to $B$. hebetor, Shim et al. (2008) found that the level of hsp90 mRNA in $P$. interpunctella was not influenced by the parasitoid envenomation. Shafeeq et al., (2017) showed that hsp90 gene in $P$. interpunctella had different levels of expression in response to $B$. hebetor envenomation under different stress conditions.

The current study aimed to compare the transcription-level of hsp90 gene by quantitative real time PCR in $P$. interpunctella and E. kuehniella in response to parasitization by the ectoparasitoid $B$. hebtor wasp.

\section{MATERIALS AND METHODS} 1.Experimental insects:

\section{1.a.Plodiainterpunctella and Ephestia kuehniella rearing:}

Adult insects used in this study were obtained from infested stored products. They were reared under laboratory conditions at temperature of 28 $\pm 2^{\circ} \mathrm{C}$ with a relative humidity of $70 \pm 5$ $\%$ and a photoperiod of 16:8 L: D (Rharrabe et al., 2010). Adults were kept in plastic jars $(17 \times 11 \times 7 \mathrm{~cm})$. They were reared on a diet consisting of cracked wheat (54\%), wheat bran (18\%), Brewer's yeast $(6 \%)$, honey (7\%), glycerin $(12 \%)$, powdered milk $(2 \%)$ and powdered sugar $(1 \%)$. 
Gene expression of heat shock protein (hsp90) in Plodia interpunctella and Ephestia kuehniella

(Lepidoptera: Pyralidae) larvae parasitized by Bracon hebetor wasp (Hymenoptera: Braconidae)

\section{1.b.ParasitoidBraconhebetor rearing:}

Strain of Bracon hebetorwas collected from wheat infested with $P$. interpunctella. The parasitoid hosts were maintained on larvae of E.kuehniella or $P$. interpunctellaat $27^{\circ} \mathrm{C}$ and $50-55 \%$ humidity (Buyukguzelet al., 2011).They were also fed on a $50 \%$ honey solution (wt:v) soaked in cotton pad. After $24 \mathrm{~h}$, parasitized host larvae were transferred to another clean plastic cup and kept under controlled conditions $\left(28 \pm 2^{\circ} \mathrm{C}, 70 \% \mathrm{RH}\right.$, and $16 \mathrm{~h}$ photophase) until adult emergence. Newly emerged wasps were used for the life history experiments.

\section{1.c.Parasitism:}

Adult parasitoids were released into plastic jars containing Five-instar larvae of E.kuehniella or P. interpunctella for $3 \mathrm{~h}$. After parasitism these larvae were quickly removed from the jarswiped with $70 \%$ ethanol and kept on thePetri dishes with paper discs until testing.All measurements were carried out using the E.kuehniella or P. interpunctella larvae.All experimental and control insects were maintained under rearing conditions according to Kryukovaet al.(2011).

\section{Molecular analysis:}

\section{2.a.RNA extraction:}

The extraction was performed using RNA Mini Kit (Ambion, 850 Lincoln Centre Drive, Foster City, United States, CA 94404, cat. no.12183018A). After isolating the RNA, the quality of RNA for each individual sample was visualized on a denaturing agarose gel. RNA concentrations were determined using spectrostar Nanodrop (BMG LAB Tech, serial number 601-04550).

Total RNA was extracted as performed in the cloning of hsp 90 genes, and $2 \mu \mathrm{g}$ of RNA per $20 \mu \mathrm{l}$. Reaction was used to synthesize first-strand cDNA. The reaction was performed in $20 \mu \mathrm{l}$ and prepared by adding $10 \mu \mathrm{l}$ of $2 \mathrm{x}$ Rt master mix into each well. Reaction mixtures were incubated for $10 \mathrm{~min}$ at $95{ }^{\circ} \mathrm{C}$, followed by 45 cycles of $15 \mathrm{~s}$ at $95^{\circ} \mathrm{C}$ and $60 \mathrm{~s}$ at $60{ }^{\circ} \mathrm{C}$, melting curve from65.0 ${ }^{\circ} \mathrm{C}$ to $95.0^{\circ} \mathrm{C}$, read every $5^{\circ} \mathrm{C}$, held for $10 \mathrm{~s}$.

\section{2.b. cDNA synthesis:}

Reverse transcription was done first-strand cDNA was synthesized using High-Capacity cDNA Reverse Transcription Kit (Applied Biosystems, 850 Lincoln Centre Drive, Foster City, California 94404, USA, Part Number 4368814). The kit contains reagents that when combined, form a $2 \mathrm{x}$ reverse transcription (RT) master mix. An equal volume of RNA sample should be added to avoid Rnase contamination.

\section{C. Quantitative real time PCR (qRT- PCR):}

Real-time PCR was run by using 2xg PCR/RTD- PCR Master Mix E3 (SABiosciencesTM, Applied Biosystems, 850 Lincoln Centre Drive, Foster City, California 94404, USA) (2X) Kit (Thermo Scientific \#K0223). Real-time PCR is widely used for quantification of mRNA levels and is a fundamental tool for basic research, biotechnology. References genes are expressed in a wide variety of tissues and cells with minimal variations in their expression levels, and thus are used to normalize data of mRNA quantification which help control for internal differences and reduce error between samples, (De Lima Rebouças et al., 2013 ;Sun etal.,2015). $\beta$-actin primers were designed using the online internet based interface (http://frodo.wi.mit.edu/primer3).

Forwardwas
TAACGAGAGGTTCCGTTGCC '3and
reverse was5' CGGT
GGTGAACGAGTAA'3.
Expression profile of hsp90
(GenBank Accession No. DQ988682)
mRNAs of P. interpunctella and E.
Kuhenilla,one primer matching the
genome of the two insects (because they
are belonging to one family pyralidae )




\section{Aida Said Kamel et al.}

was designed to amplify the complete coding sequence (CDS) of hsp90 gene from total genomic DNA by using the online internet based interface (http://frodo.wi.mit.edu/primer3).

Sequence of hsp90 forward Primer was: 5'ATGATTGGGCAGTTCGGTGT'3 and reverse primer was: 5'CGGACGCACAGTGAATGAAC'3.

Triplicate samples were used in all measurements of qRT-PCR.

\section{2.d. Quantitative real time PCR (RT- qPCR) analysis:}

Data analysis from real time PCR was achieved using relative quantification (Livak and Schmittgen, 2001). Quantifying the relative changes in gene expression using real-time PCR requires certain equations, assumptions, and the testing of these assumptions to properly analyze the data. The $2^{-\Delta \Delta C t}$ method was used to calculate relative changes in gene expression determined from real-time quantitative $\mathrm{PCR}$ experiments.

Delta $\mathrm{Ct}=\mathrm{Ct}_{\text {gene test }}-\mathrm{Ct}_{\text {housekeeping gene }}$ Delta Delta $\mathrm{Ct}=\Delta \mathrm{Ct}$ sample $-\Delta \mathrm{Ct}$ calibrator $\mathrm{RQ}=$ Relative quantification $=2^{-\Delta \Delta \mathrm{Ct}}$

Where $\mathrm{Ct}$ means cycle threshold and defined as the number of cycles required for the fluorescent signal to cross the threshold.

\section{Statistical analysis:}

Data of the experiments were made using SPSS program, Version 20.0, expressed as mean \pm standard error (SE). Levels of significance for differences of means were determined using Student's ttestfor independent. The level of significance for each experiment was set at $\mathrm{P} \leq 0.05$ and $\mathrm{P} \leq 0.01$.

\section{RESULTS AND DISCUSSION}

Heat shock proteins (hsps) have been widely studied in many fields of biology and a large number of publications describe their molecular and physiological functions. These were highly conserved and ubiquitous proteins that are best known for the responsiveness to different stresses (Yi et al., 2018). Success in analysis of gene expression by qRT-PCR depends on the appropriateness of the designed primer and probes to be used. The specificity technique is internally linked to annealing of the primer to their complementary targets. For this selection of nucleic acid sequence is an essential step in designing primers for qRT-PCR (Sobhy and Closon, 2012). In the current study, the expression changes of hsp90 gene in $5^{\text {th }}$ larval instars of $P$. interpunctella and E. kuehniella parasitized by $B$. hebetor were followed up to $72 \mathrm{~h}$ after the parasitism. Significant downregulated of hsp90 gene was observed at all interval periods in response to the parasitism. With exception, a high significant up regulation of the gene was recorded after $48 \mathrm{~h}$ of parasitism in $P$. interpunctella host larvae. The level of hsp90 gene in parasitized $P$. interpunctella larvae (Fig. 1) was significantly down regulated at $12 \mathrm{~h}$,it recorded $(0.469 \pm 0.10)$ and high significantly upregulated at $48 \mathrm{~h}$, it recorded $(1.824 \pm 0.128)$ post parasitization compared with control. While a high significant down regulation of the gene was found at 24 and $72 \mathrm{~h}$ post parasitization and recorded $(0.327 \pm 0.07)$ and $(0.112 \pm 0.04)$,respectively compared with control.

There was obvious positive relationship between hsp90 level and the time of post parasitism in case of parasitized E. kuehnilla larvae (Fig. 2). The level of hsp90 gene was highly significant downregulated in all treated larvae at 12, 24,48 and $72 \mathrm{~h}$ after parasitization compared with control. They recorded $(0.08 \pm 0.04,0.131 \pm 0.05,0.213$ $\pm \quad 0.07, \quad 0.395 \pm 0.05)$, respectively.However, the rate of gene expression was significantly decreased in all time intervals of post parasitism compared with the control.

In the present result the downregulation of hsp90 was unexpected because parasitization induced host 
cellular stress, disrupted physiology and induced immune defense reaction, in haemolymph. This agrees with the finding of Caron et al.(2008) who reported that parasitization induces imune reaction by production of reactive oxygen species (ROS) which lead to protein denaturation or proteotoxicity in the host cell itself, and is toxic to the parasitoid offspring of the host larvae. Meanwhile, Wang et al. (2016) ; Shafeeq et al.( 2017) concluded that hsp90 suppresses the immune development and protect the damage of cellular structure and function. But despite the upregulation of hsp90, the opposite was observed in the current study. The down-regulation of hsp90 of all treatment of the two host larvae except at 48 in case P.interpunctella might suggest that, subsequent parasitization by B.hebetor wasp, on host larvae causes a decrease in hemolymph immunity and down regulate the hsp90 gene.

The upregulation of hsp90 gene in P.interpunctellae host larvae at $48 \mathrm{~h}$ after envenomation due to stress of parasitism, might increase immune response of host hemolymph to protect the host larvae from the venom of this wasp. Subsequent parasitization by $H$. hebetor, on host larvae causes a decrease in hemolymph immunity and down regulate the hsp90 gene in other treatments in $P$. Interpunctella and E.Kuhenilla. Many researchers reported that there wasa significant down regulation of the level of hsp90 host-parasite interaction in different insects. In addition, Rinehart et al. (2002) found that the level of hsp90 was slightly down regulated in Sarcophaga crassipalpis injected by Nasonia vitripennis venom, when compared to unenvenomated controls. Zhu et al. (2013) reported similar interactions between Pieris rapae (Lepidoptera: Pieridae) and its parasitoid Pteromalus puparum (Hymenoptera:Pteromalidae) which lead to down-regulation of hsp90 in parasitized pupae. The level of hsp70 in $P$. interpunctella larvae was gradually increased with a high level until 4 days after envenomation by $B$. hebetor (Shim $e t$ al., 2008).

Gene expression of the hsps in Bombyx mori eggs parasitized by Telenomus theophilaewas differentially influenced by parasitization. Upregulation of hsp genes may play essential roles in silkworm eggs against parasitoids (Wang et al., 2016).In addition,Shafeeq et al. (2017) reported that the genes associated with the host larvae of $P$. interpunctella were differentially influenced by $B$. hebetor envenomation, and stress and immune responses were upregulated,after envenomation. While those associated with metabolism and development were downregulated. Meanwhile, Fang et al.(2016) cleared that only venom components from endoparasitoid Pteromalus puparum produced antimicrobial peptides (AMPs). Moreover, Calreticulin venom component, suppress cellular immune responses in its host Pieris rapae.Other venom components from this parasitoid wasp suppress the host genes cecropin and lysozyme involved in humoral immune responses. In addition, Rivers et al. (2009) stated that the venoms of several ectoparasitoids contain paralytic factors and developmental suppression that interact with hormones and prevent molting of the host so that the parasitoids are not removed from the host's external surface. Moreover, Beckage and Gelman (2004) concluded that the venoms of several ectoparasitoids contain endocrine disruptors that reprogram the development. In early study, Lezzi (1996) suggested that there is a functional connection between hormones and heat shock regulatory systems. Therefore hsps play an essential role in the biological process of development. Moreover, some authors studied the gene expression under different biotic stress. They noticed that the envenomation of the wandering fifth instar 


\section{Aida Said Kamel et al.}

larvae remarkably increased hsp90 levels by 2.8 -folds. Its level was highly elevated from the first day after envenomation then slightly downregulated after 4 days. However, the levels of hsp90 did not change in the feeding or starved envenomated larvae compared to the control over the experimental period. Nonetheless, hsp90 gene up regulation was observed in several insects subjected to biotic or abiotic stresses. The expression of hsp90 in Sitophilus Zea maize exposed to different stress factors of heat shock and cold shock (Tungjitwitayakul et al., 2015) or ultraviolet-C and microwave irradiation(Tungjitwitayakul et al., 2016) was significantly increased in responses to the stress. This increase in the gene expression indicates that the chaperone actions of hsp90s are involved in tolerance in stressed cells (Morano et al., 2012).
Hsp90s appears to participate in the maintenance of muscle structures and down regulation of the hsp90 system causes defects in muscle cells and lead to paralysis (Gaiser et al., 2011). Zhu et al. (2013) concluded that the transcription of hsp could be a component of the syndrome of parasitized hosts. The regulation of the hsps expression in an insect after parasitization could protect the host's tissues and the developing parasitoid from noxious agents produced by the host's immune response.

In conclusion, the present data indicated that parasitism had a significant impact on suppression of hsp90 genes. As the gene down regulation might be play an important role in host paralysis and inhibit its development to create the appropriate conditions for parasitoid offspring growth.

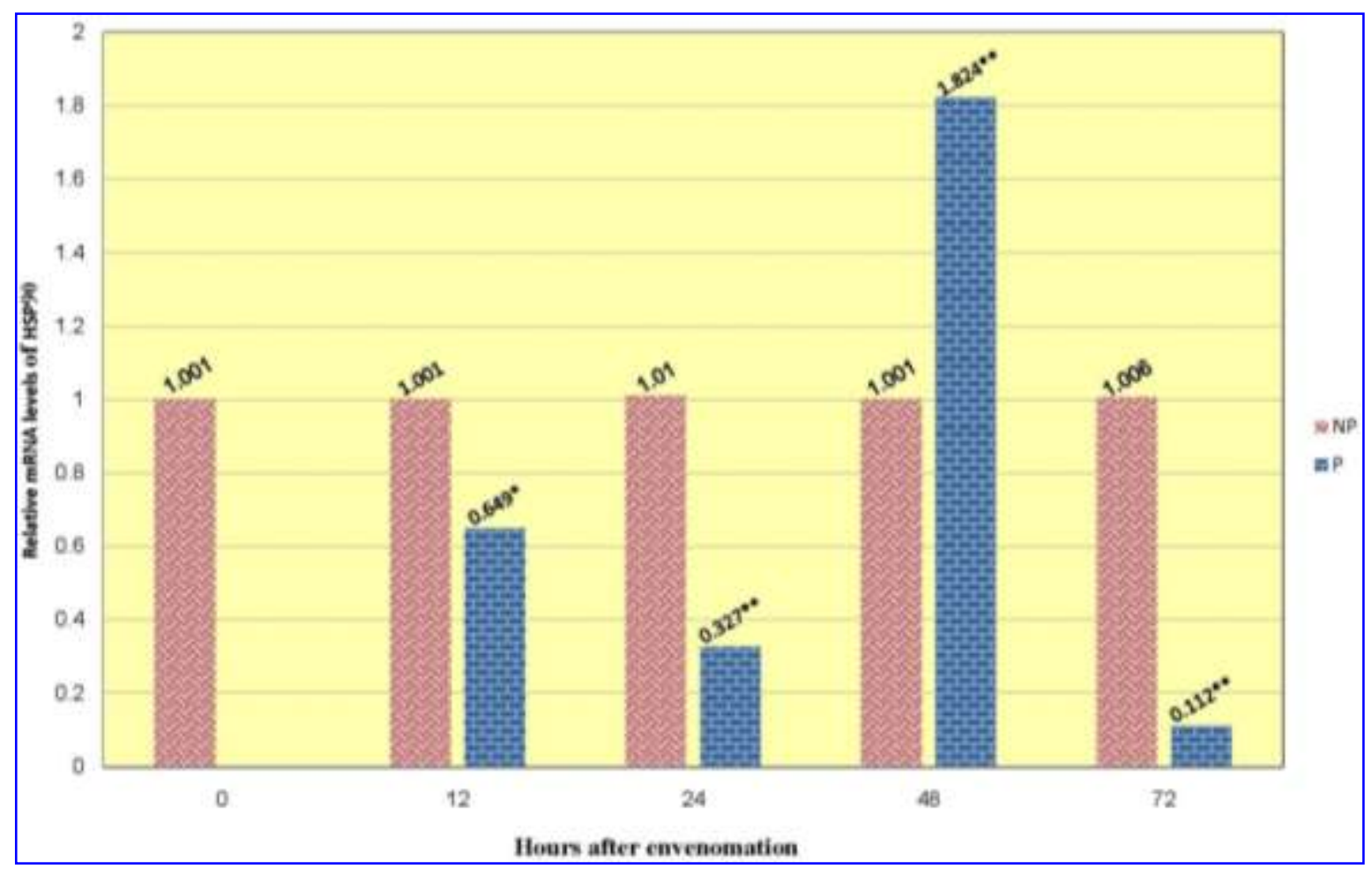

Fig. 1.The expression levels of hsp90 gene in parasitized $P$. interpunctella $5^{\text {th }}$ larval instar by $B$. hebtor at different time intervals post parasitization. The mRNA expression levels for all samples were assessed by qRT-PCR.

* Significance at $\mathrm{P} \leq 0.05$. $*$ High Significance at $\mathrm{P} \leq 0.01$.

NP: non parasitized larvae, P: parasitized larvae 
Gene expression of heat shock protein (hsp90) in Plodia interpunctella and Ephestia kuehniella (Lepidoptera: Pyralidae) larvae parasitized by Bracon hebetor wasp (Hymenoptera: Braconidae)

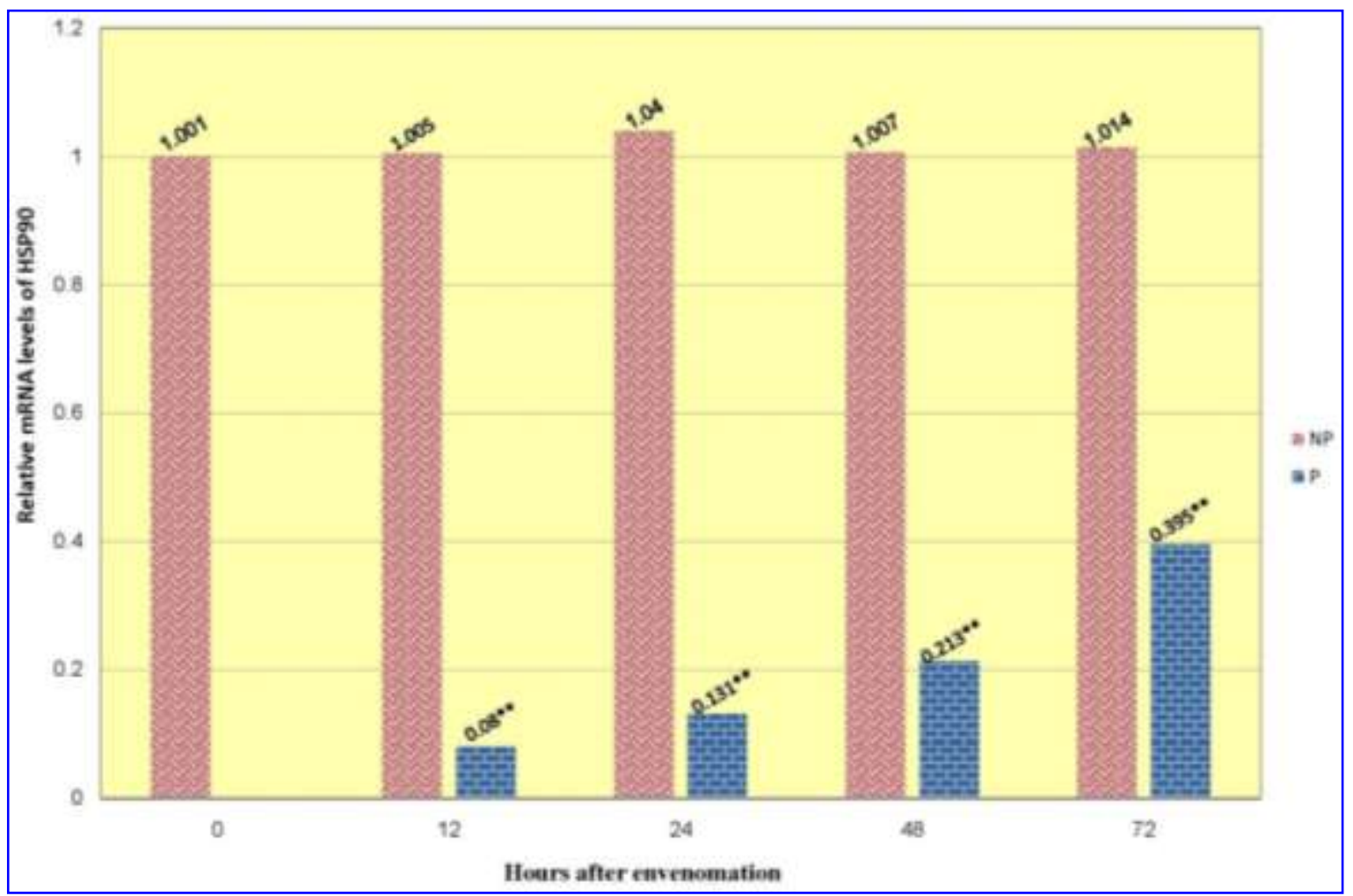

Fig. 2.The expression levels of hsp90 gene in parasitized $E$. kuehniella $5^{\text {th }}$ larval instarby $B$. hebtor at different time intervals post parasitization. The mRNA expression levels for all samples were assessed by qRT-PCR".

* Significance at $\mathrm{P} \leq 0.05$. ${ }^{*}$ High Significance at $\mathrm{P} \leq 0.01$.

NP: non parasitized larvae, P: parasitized larvae

\section{Acknowledgement:}

The authors would like to thank members of the Marine Genomics Laboratory, Zoology Department, Faculty of Science, Benha University, Benha, especially thanks go to Dr. Hany A. Abdel-Salam, and Sahar Mohamed for their constructive help.

\section{REFERENCES}

Beckage, N.E. and Gelman, D.B.(2004).Wasp parasitoid disruption of host development: implications for new biologically based strategies for insect control. Annu. Rev. Entomol., 49: 299-330.

Belda,C.and Riudavets, J.(2010). Attraction of the Parasitoid Anisopteromalus calandrae (Howard) (Hymenoptera: Pteromalidae) to odors from grain and stored product pests in a $\mathrm{Y}$ Tube to Olfact. Biol. Cont., 54: 2934.

Caron, V. ; Janmaat, A.; Ericsson, J. and Myer, J. (2008). Avoidance of the host immune response by a generalist parasitoid, Compsilur aconcinnata.Meigen.

Entomol., 33: 517-522.

Chen, H.; Opit, P.G.; Sheng, P.and Zhang, $\mathrm{H}$. andprogenqualityof

Habrobracon hebetor Say (Hymenoptera Brachonida) after cold storage. Biological control, 58(3):2 55-261.

Darwish, M.; Abd-Elwadod, M.and Mahmoud, M.(2003). Microbiological and molecular detection of Pseudomonas aeruginosa 


\section{Aida Said Kamel et al.}

nasogastric tube fed geriatric patients. Afr. J. Microbiol. Res., 6(21): 4521-4526.

De Lima Rebouças, E.; do Nascimento Costa, J.J.; Passos, J.M.; de Sousa Passos, R.J.; van den Hurk, R.and Viana Silva, J.R .(2013). Real Time PCR and Importance of Housekeepings Genes for Normalization and Quantification of mRNA Expression in Different Tissues. BrazilianArchies of Biological and Technology, 56(1):143-154.

Fang, Q.; Wang, B.B.;Ye, H.X.; Wang, F. and Ye, Y.G.(2016).Venom of Parasitoid Pteromalus

puparum impairs host humoral antimicrobial.Activity by Decreasing host cecropin and lysozyme gene toxins expression. Basel, 8(2): 52. doi: 10.3390/toxins 8020052 .

Felts, S.J., et al.(2000).The hsp90-related protein TRAP1 is a mitochondrial protein with distinct functional properties, J. Biol. Chem. 275, 3305- 3312.

Gaiser, A.M.; Kaiser, C.J.O.; Haslbeck, V. and Richter, K.(2011). Down regulation of the Hsp90 system causes defects in muscle cells of Caenorhabditis Elegans. PLoS ONE 6(9). :e25485. doi: 10.1371/ journal.pone. 0025485 .

Krishna, P. and Gloor, G.(2001).The Hsp90 family of proteins in Arabidopsis thaliana.Cell Stress Chaperones, 6(3): 238-246.

Kryukova, N.A.; Dubovskiy, I.M.; Chertkova, E.A.; Vorontsova, Y.A.L.;Slepneva, I. A. And Glupov, V. V. ( 2011). The effect of Habrobracon hebetorvenom on the activity of the prophenoloxidase system, the generation of reactiveoxygen species and encapsulation in the haemolymph of Galleria mellonellalarvae. Ins. Physiol.,57: 796-800.
Lezzi, M. and Puffing, C.(1996). Supramolecular aspects of ecdysone action. Metamorphosis: Post-Embryonic reprogramming of gene expression in Amphibian and Insect Cells. (eds. L.I. Gilbert, J.R. Tata, \& B.G. Atkinson), pp. 145- 173.

Livak, K.J. and Schmittgen, T.D.( 2001). Analysis of relative gene expression data using real-time quantitative PCR and the 2(-Delta Delta C (T) )Method. Methods, 25: 402-408.

Maafi, A.M. and Chi, H.(2006). Demography of Habrobracon hebetor (Hymenoptera: Braconidae) on two pyralid hosts (Lepidoptera: Pyralidae). Ann. Entomol. Soc. Am., 99: 84-90 .

Mohandass,S.; Arthur, F.H.; Zhu, K.Y. and Throne, J.E. (2007). Biology and management of Plodia interpunctella (Lepidoptera: Pyralidae) in stored products. J. Stored Prod. Res., 43: 302- 311.

Morano, K.A.;Grant, C.M. and MoyeRowley, W.S. (2012). The response to heat shock and oxidative stress in Saccharomyces cerevisiae. Genetics, 1190(4): 1157-1195.

Nguyen, T.T.; Michaud, D. and Cloutier, C.A. (2009). Proteomic analysis of the aphid Macrosiphum euphorbiaeunder heat and radiation stress. Insect Biochem. Mol. Biol., 39: 20- 30 .

Rinehart, J.P.; Denlinger, D.L. and Rivers,D.B.(2002). Up regulation of transcripts encoding select heat shock proteins in the flesh fly Sarcophaga crassipalpis in response to venom from the ectoparasitoid wasp Nasonia vitripennis. J. Invert. Pathol., 79: 62-63.

Rivers, D.B., Dani, M.P. and Richards EH.(2009). The mode of action of venom from the endoparasitic wasp 
Pimpla Hypochondriaca (Hymenoptera: Ichneumonidae) involves $\mathrm{Ca} 2+$-dependent cell death pathways. Arch. Ins. Bioch. and Physiol., 71: 173-190.

Schölle M., (2010). Biological control of stored-product insects in commodities, food processing facilities and museums.10th International Working Conference on Stored Product Protection 546-603. Shafeeq, T.U.; Abdin, Z. and Lee, K.Y. (2017). Induction of stress- and immune associated genes in the Indian meal moth Plodia interpunctella against envenomation. Arch. Ins. Bioch. and Physiol., 96(2), xx-yy.

Shim, J.K.; Ha, D.M.; Nho, S.K.; Song, K.S. and Lee, K.Y. (2008). Upregulation of heat shock protein genes by envenomation of ectoparasitoid Bracon hebetor in larval host of Indian meal moth Plodia interpunctella. J. Invert. Pathol., 97: 306-309.

Sla'ma, K. and Lukas, J.(2011).Myogenic nature heart beat and intestine apersitals by neuro musculature paralysis caused by sting of brachonoid. J. Ins. Physiol., 57: 251-259.

Sobhy, H. and Colso, P. ( 2012). Gemi: PCR Primers Prediction from Multiple Alignments. Comparative and Functional Genomics, PMCID: PMC3535827 PMID: 23316117 Published online 2012 Dec $19 . \quad$ doi: $\underline{10.1155 / 2012 / 783138}$

Sõti, C.; Nagy, E.; Giric, Z.; Vígh, L.P. and Csermely, P. (2005). Ferdinandy. Heat shock proteins as emerging therapeutic targets. Br. J. Pharmacol., 146(6): 769-780.

Tungjitwitayakul, J.; Tatun, N.; Vajarasathira, B. and Sakurai, S. (2015). Expression of heat shock protein genes in different developmental stages and after temperature stress in the Maize weevil (Coleoptera: Curculionidae). J. Econo. Entomol., 108(3): 13131323.

Tungjitwitayakul, J.; Tatun, N.;Vajarasathira, B. and Sakurai, S.( 2016).Effects of ultraviolet-C and microwave irradiation on the expression of heat shock protein genes in the Maize weevil (Coleoptera: Curculionidae). Europ. J. Entomol., 113: 135-142.

Wang, L.; Zhao, Y.; Qian, C.; Wei, G.; Zhu, B. and Liu C.(2016).Gene expression of heat shock proteins in Bombyx mori egg parasitized by a parasitoid wasp, Telenomus theophilae. J. Zoolo., 48(2): 507512.

Wegele, H.; Müller, L. and Buchner, J. (2004). Hsp70 and Hsp90 a relay team for protein folding, Rev. Physiol. Bioch. and Pharm., 151: 144.

Yi, J.; Wu, H.; Liu, J.; Lai, X.; Guo, J.; Li, D., et al. (2018). Molecular characterization and expression of six heat shock protein genes in relation to development and temperature in Trichogram machilonis. PLoS ONE 13(9): https://doi.org/10.1371/journal.pon Published: September 18, 2018

Young, J.C., Moarefi, I., Hartl, F.U. (2001). Hsp90: a specialist but essential protein-folding tool. J. Cel. Biol. 154: 267-273.

Zhao, L., Jones, W.A. (2012). Expression of heat shock protein genes in insect stress responses. The Information Systems J., 9: 93-101.

Zhu, J.Y.; Wu, G.X.; Ye, G.Y. and Hu, C. (2013). Heat shock protein genes (hsp20, hsp75 and hsp90) from Pieris rapae: Molecular cloning and transcription in response to 
Aida Said Kamel et al.

parasitization by Pteromalus puparum. Ins. Sci. 20: 183-193.

التعبير الجيني لبروتين الصدمة الحرارية 90 في يرقات البوليبيا إنتربنكتيلا والإيفستيا كبيونيلا (حرشفية الأجنحة ـ

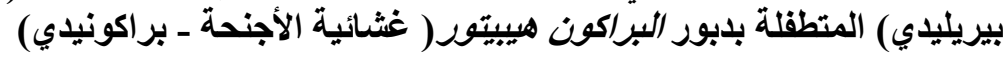

عايدة سعيد كامل ممتاز- روحية حسن رمضان ـ فاتن فريد أبو الدهب ـ مني فوزي عبد العزيز - هبة عبد الخالق

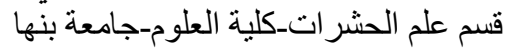

المستخلص

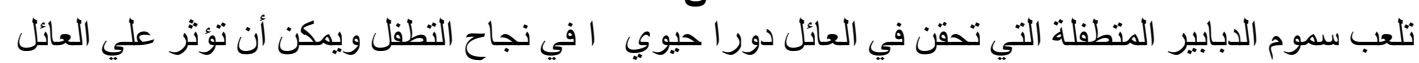

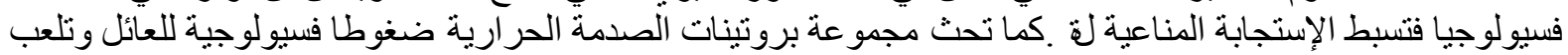

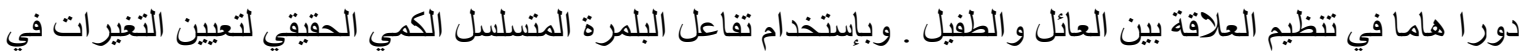

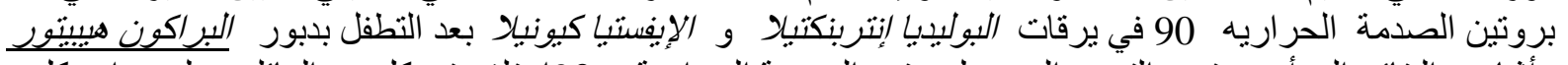

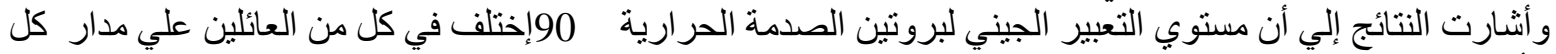

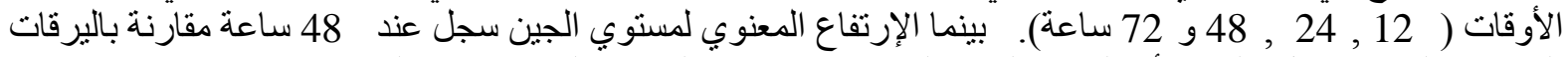

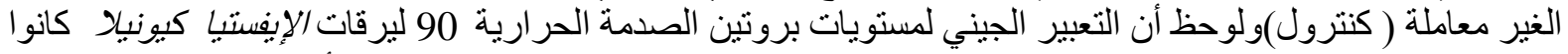

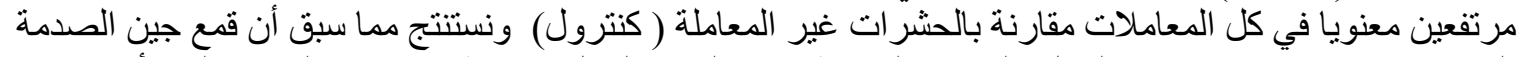

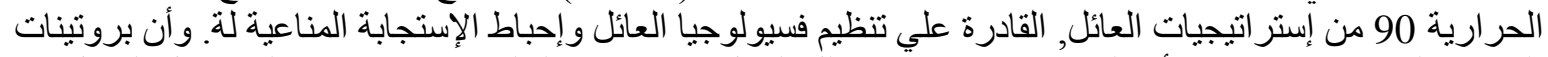

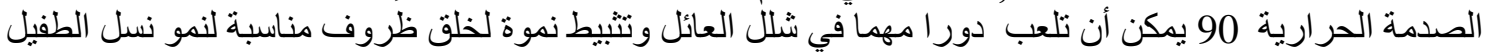

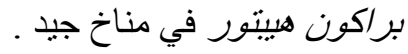

